\title{
Water Pollution History of Switzerland Recorded by Sediments of the Large and Deep Perialpine Lakes Lucerne and Geneva
}

\author{
Florian Thevenon • John Poté
}

Received: 1 June 2012 / Accepted: 26 September 2012 /Published online: 10 October 2012

(C) Springer Science+Business Media Dordrecht 2012

\begin{abstract}
This review addresses the quantification of anthropogenic pollutants in lacustrine sediments by multidisciplinary analyses including: chronostratigraphy using radioisotopes $\left({ }^{137} \mathrm{Cs}\right)$ and radiocarbon dates $\left({ }^{14} \mathrm{C}\right)$, trace metal analysis, faecal indicator analysis, as well as antibiotic-resistant genes by molecular analysis. Sediment cores from lakes Lucerne and Geneva that are located at a distance of $150 \mathrm{~km}$ from each other reveal a synchronous increase in anthropogenic trace metals $(\mathrm{Pb}, \mathrm{Cu}, \mathrm{Zn}$, and $\mathrm{Mn})$ following the industrial revolution in Europe about 1850. In both lakes, the peak of water pollution by toxic metals due to discharge of industrial wastewaters was reached in the middle of the twentieth century. During the second part of the twentieth century, both sites show a decrease in metal pollution following the implementation of wastewater treatment plants. On the contrary, the Vidy Bay of Lake Geneva where the treated wastewaters from the city of Lausanne are released since 1964 points out a dramatic increase in trace metal deposition. Later, a high increase in organic matter deposition, in bacteria (Escherichia coli and Enterococcus faecalis) activity as well as antibiotic-resistant genes and bacteria occurred into the bay, simultaneously with the eutrophication of the large and deep
\end{abstract}

F. Thevenon · J. Poté $(\bowtie)$

Institut F.-A. Forel, Université de Genève,

CP 416, 1290 Versoix, Suisse, Switzerland

e-mail: john.pote@unige.ch perialpine lakes in the 1970 s due to excessive external nutrient loading.

Keywords Perialpine lakes · Sediment cores · Trace metal $\cdot$ Bacteria $\cdot$ Wastewater $\cdot$ Pollution

\section{Introduction}

The pollution of lake and reservoirs by different types of contaminants constitutes a major environmental concern in many parts of the world and a major threat for the world's freshwater resources (Vörösmarty et al. 2010). In particular, effluent waters from wastewater treatment plants (WWTPs) represent major sources of contamination for aquatic environments, including the water column and the sediment compartment. As a result, the contamination by inorganic pollutants (toxic metals) and pathogenic bacteria is an urgent concern in numerous coastal ecosystems, estuaries, lakes and rivers across the world (e.g. LaLiberte and Grimes 1982; Schwarzenbach et al. 2006). Indeed, sediment contamination by pathogenic organisms, toxic trace metals and other micro-pollutants are causing adverse effects to ecosystems and hazardous human health risks (Salomons and Förstner 1984; Verwij et al. 2004; Wang et al. 2004). For these reasons, the processes of deposition (or sedimentation), transformation and remobilisation of the contaminants over time and under changing environmental conditions (e.g. climate variations) should be examined extensively. 
Historical records of anthropogenic pollutants in aquatic environments can be reconstructed by studying lake sediments. In fact, the contaminants discharged to the environment are washed by rainwater, transported to aquatic ecosystems, and deposited and preserved in sediments that continuously accumulate with time. As a consequence, the characterisation and the quantification of the pollutants entrapped in welldated sediment cores allow (1) the quantification of the natural content of trace elements (geochemical background) that can be further used to calculate the anthropogenic enrichment signal, (2) the evaluation of the modern pollution level in regards to natural (climate-induced) and (pre-) historical variations, and (3) the assessment of the temporal evolution of the contamination and its relationship with past human activities (settlement, land-use and metallurgy; Thevenon et al. 2011a).

Lake and river systems are particularly exposed to anthropogenic pollutants because the contaminant loads accumulate in the sediments. Their remobilisation and their return to the hydrosphere either by sediment re-suspension or by infiltration into the groundwater thereby constitute a major risk for water quality. The modification of environmental conditions such as $\mathrm{pH}$, redox potential, organic matter supply or ligand concentration can lead to the release of trace metals from the sediment to the water column (desorption) and subsequently increase their bioavailability (Cantwell et al. 2002; Lors et al. 2004). Many studies have been conducted to assess the quality of surface sediments, the spatial distribution of contaminants and their potential effects in contrasting aquatic ecosystems (e.g. Schwarzenbach et al. 2006; Poté et al. 2008). These studies indicate that (1) sediment quality of many coastal waters in the world is largely impacted by the proximity to urban centres and industrial or agricultural activities; (2) trace metals, hydrophobic organic contaminants and other toxic substances dangerously accumulate in sediments and (3) these contaminants can be remobilised under the influence of chemical or physical processes but also via microbial metabolism. Hence, the release from sediments into the water column of multiple pollutants exerts toxics effects on indigenous fauna and flora of the ecosystem.

To the present day, only a few studies have been carried out on sedimentary records of polluted aquatic ecosystems in order to describe the relationships linking the temporal distribution of inorganic and organic pollutants with bacterial activity. The objectives of this contribution are to (1) describe the approach used for collecting and dating short gravity cores, (2) summarise the physicochemical and bacteriological methods that can be applied to evaluate anthropogenic disturbances in contaminated lakes, (3) investigate the historical pollution of two well-dated lacustrine records from Central Europe (lakes Geneva and Lucerne, Switzerland) and (4) to assess the impact of the anthropogenic pollution in the Vidy Bay which is the most contaminated area of Lake Geneva (the largest freshwater reserve in Europe) due to the local release of treated wastewaters. Previous data documented the accumulation of contaminants in sediments close to this recreational area on the bay's shoreline (Loizeau et al. 2004; Pardos et al. 2004). Some studies have already focused on the physicochemical characteristics of the surface sediments of Vidy Bay and on the spatial distribution of organic compounds, faecal indicator bacteria, trace metals and hydrophobic organic compounds (e.g. Poté et al. 2008; Haller et al. 2009). However, there is a lack of sedimentary records linking bacterial abundance, activities, diversity and functional characterisation in these metalcontaminated sediments.

\section{Studied Lakes and Coring Sites}

\subsection{Lake Lucerne}

Lake Lucerne (or Vierwaldstättersee) is a large lake (surface area of $116 \mathrm{~km}^{2}$ and water volume of $12 \mathrm{~km}^{3}$ ) located at an elevation of 434 ma.s.1., at the northern Alpine front in Central Switzerland (Fig. 1). Its maximum depth is $214 \mathrm{~m}$ (average depth is $104 \mathrm{~m}$ ), and the lake encompasses four steep-sided basins separated by moraine ridges which are fed by four alpine rivers (Reuss, Muota, Engelberger Aa and Sarner Aa; Fig. 1) draining a large part of the catchment area of about 2,250 $\mathrm{km}^{2}$. Lake Lucerne is meromictic, with one complete overturn generally preceded by a significant rise of the hypolimnic temperature. The lake underwent a period of moderate eutrophication from 1960 to 1979 (Bührer and Ambühl 2001).

In 2005, a 166-cm-long core (4WS-05, Fig. 1) was collected in the middle of the Chrüztricher Basin (Swiss coordinates, 669.397/209.079) at $110 \mathrm{~m}$ water 
Fig. 1 Center Satellite image showing the position of the two large and deep perialpine lakes Lucerne and Geneva distant from about $150 \mathrm{~km}$ (the Alpine regions located above $2,000 \mathrm{~m}$ are covered by snow). Bathymetric maps (contour interval of $40 \mathrm{~m}$ ) of Lake Lucerne (upper panel) and Lake Geneva (lower panel) showing the location of the main cities, rivers and coring sites

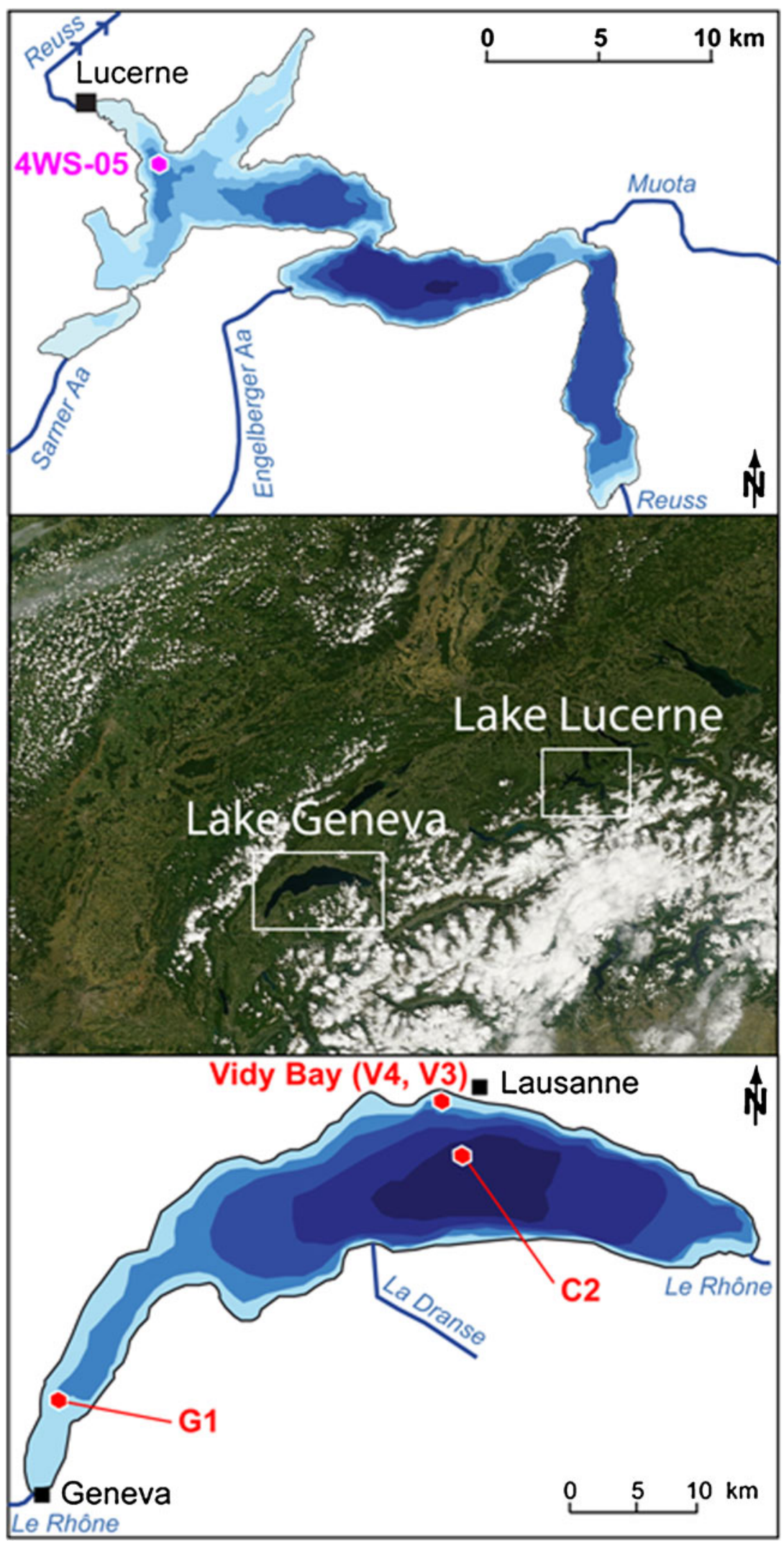


depth. This core has been previously analysed for combustion residues (Thevenon and Anselmetti 2007), and natural and anthropogenic trace element distribution (Thevenon et al. 2011b, c).

\subsection{Lake Geneva}

Lake Geneva (or Léman; Fig. 1) is the largest freshwater reservoir in Western Europe, with a volume of $89 \mathrm{~km}^{3}$, a surface area of $580 \mathrm{~km}^{2}$ and a maximum depth of $309 \mathrm{~m}$ (average depth is $154 \mathrm{~m}$ ). The lake is located on the southwestern part of the Swiss Plateau at an elevation of 372 ma.s.l. The Rhône and the Dranse rivers are the major tributaries to the lake (Fig. 1), draining a part of catchment area of about $7,975 \mathrm{~km}^{2}$. Lake Geneva is a meromictic lake, with intense vertical mixing rarely affecting the entire water column (complete turnover favoured by cold weather; Livingstone 1997). The lake was considered eutrophic in the 1970s and has become mesotrophic in the 1980s after a drastic reduction of phosphorus inputs (Dorioz et al. 1998).

Approximately 700,000 people are supplied with water from Lake Geneva. The pumping station of St. Sulpice that provides about $60 \%$ of drinking water to the city of Lausanne (the largest city on the lakeshore) is located at less than $4 \mathrm{~km}$ from Vidy Bay (Fig. 6). Vidy Bay is the most contaminated area of Lake Geneva due to the release of treated domestic and industrial wastewaters into the bay (Pardos et al. 2004; Poté et al. 2008). Lausanne generates large volumes of domestic and industrial wastewaters which are released into Vidy Bay (1) through the outlet pipe of the WWTP built in 1964, (2) via the Flon River which collects surface and wastewater from the western part of the city and (3) from the Chamberone River which collects surface runoff waters from its natural drainage basin and urban runoff waters from the city of Lausanne. The WWTP, initially set up with mechanical and biological treatments for 216,000 equivalent inhabitants, was expanded in 1976, but its effluents were still being discharged $300 \mathrm{~m}$ from the lakeshore at depth of $15 \mathrm{~m}$. The outlet pipe was eventually extended to $700 \mathrm{~m}$ from shore, at $35 \mathrm{~m}$ depth, in 2001.

Between 2009 and 2011, two sediment cores were retrieved from the Bay of Vidy: a 36-cm-long core V3 (534.682/151.538) which is the coring location closest to the WWTP outlet pipe discharge, and core V4 (40 m water depth, $62 \mathrm{~cm}$ length, 534.682/151.410, distance to coast $\sim 715 \mathrm{~m}$; Figs. 1 and 6 ). Two additional cores were collected in the deepest parts of Grand and Petit lakes (Fig. 1): (1) a 60-cm-long core G1, at $51 \mathrm{~m}$ water depth in the centre of the Petit Lac (502.613/122.938) and (2) a 130 -cm-long core $\mathrm{C} 2$, at $304 \mathrm{~m}$ water depth in the centre of the Grand Lac (534.504/146.178).

\section{Methods}

\subsection{Sediment Sampling and Dating}

The boat "La Licorne" of the Institute F.-A. Forel (Fig. 2) was used for retrieving sediment cores from Lake Geneva using a gravity corer. A gravity corer was also used to collect sediment deposits from Lake Lucerne (Fig. 2). After their collection, the cores were brought to the laboratory, opened and sliced continuously every 1 or $2 \mathrm{~cm}$ for geochemical analyses and microbiological analysis. The sediment samples were placed in sterile plastic containers (stored in an icebox) and treated in the laboratory within $24 \mathrm{~h}$ for microbiological analysis. For chemical analysis, the sediment samples were frozen, freeze-dried and ground manually into a fine homogenised powder.

The dating of the recent sediments (upper part of the core) is based on the measurement of anthropogenic cesium $\left({ }^{137} \mathrm{Cs}\right)$ emitted by the atmospheric weapon tests after 1950 and its emission maximum in 1963/1964; and the detection of the Chernobyl accident that occurred in 1986 in Ukraine (Fig. 3). Additional radiocarbon dates are used for dating the oldest sediments (lower part of the core). Natural (e.g. tephra layer or flood event) or anthropogenic fingerprints (e.g. river derivation or pollutant emission) can also be used for refining the chronostratigraphy. That is the case for the fossil fuel combustion particles observed in the upper part of Lake Lucerne core and for the turbidite deposited below $163 \mathrm{~cm}$ downcore (Fig. 3; details in part 4.1). This event that occurred 2,200 years ago has been detected in different subbasins of the Lake Lucerne and interpreted as triggered by a large northern Alpine earthquake (Schnellmann et al. 2002; Strasser et al. 2006).

\subsection{Physicochemical Parameters}

A multiproxy approach is recommended for reconstructing climate and human-induced paleo-environmental 
Fig. 2 Upper part The boat "La Licorne" of the Institute F.-A. Forel used for retrieving sediment cores from Lake Geneva. Lower part, left Photograph of a sediment core (gravity corer of the Geological Institute of ETH Zurich) extruding the 166-cm-long sediment core (4WS-05) from Lake Lucerne, and (central part) a picture of the opened core. right Scanning electron microscopy images of two fossil fuel combustion products derived from the successive combustion of coal and oil found at 14 and $9 \mathrm{~cm}$ downcore, respectively

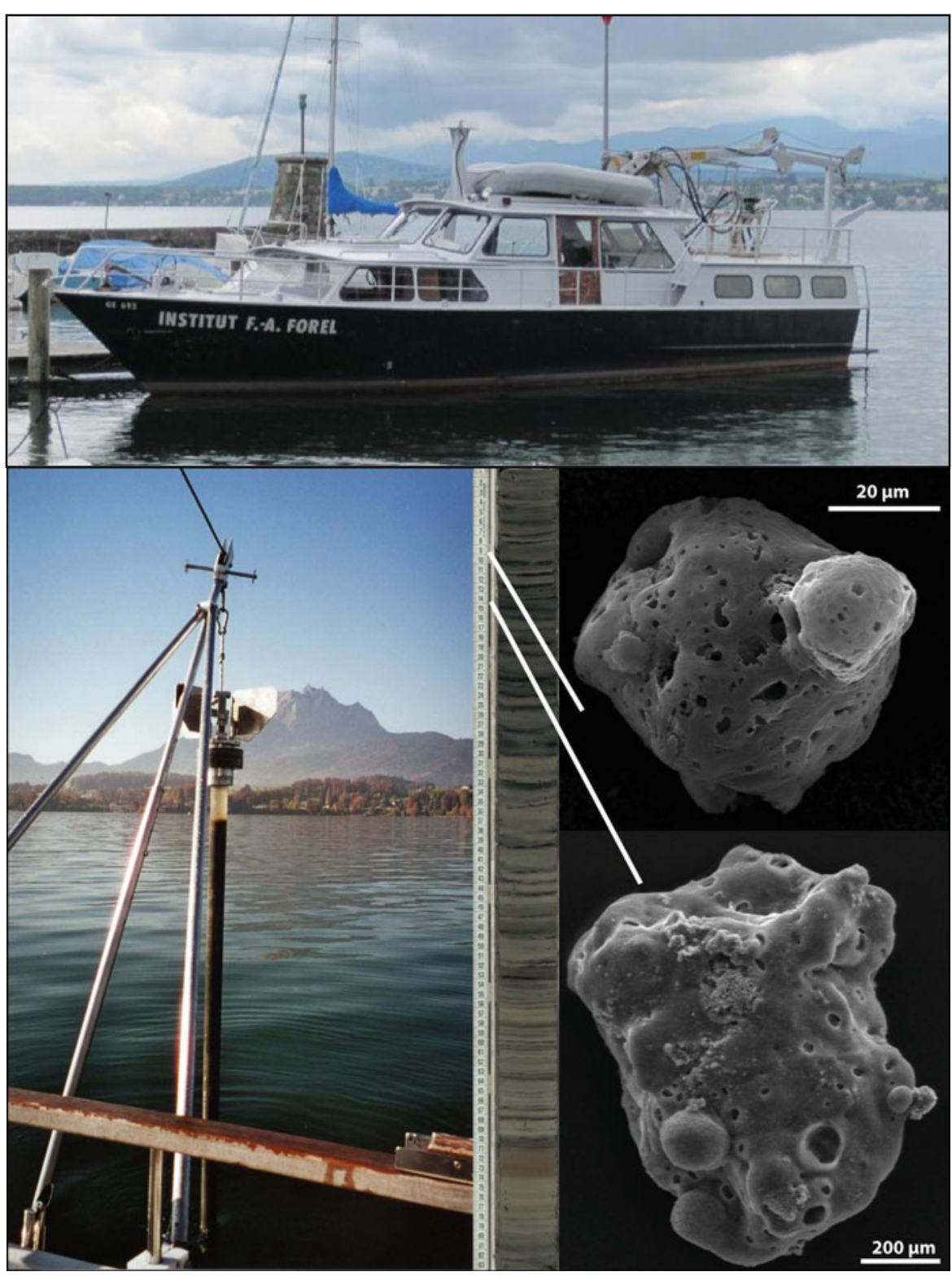

changes imprinted in sediment deposits. The sediments can be analysed by physical (e.g. mineralogy, density and grain size) and chemical (e.g. phosphorous, nitrogen and organic carbon) properties. In fact, the temporal distribution of different parameters allows apprehending the driving sedimentological processes that are influenced by the hydrodynamic of the environment (e.g. climate-induced hydrological changes) and by the source contributions (weathering of natural trace elements and human disturbances). The methods used for routine analysis of physicochemical parameters in sediments, including the metal trace elements analysis by
ICPMS, are described in detail in our previous studies (Thevenon et al., 2011a, b).

\subsection{Bacteria Analysis}

The bacterial and archaeal communities in sediment samples from the bay of Vidy were performed using molecular methods (Haller et al. 2011). The faecal indicators bacteria (FIB) including Escherichia coli and Enterococcus faecalis (ENT) multi antibiotic resistant (MAR) were performed by the methods as described in Haller et al. (2009) and Thevenon et al. 
Fig. 3 Age model of the sediment core from Lake Lucerne (4WS-05), using the appearance of combustion products as stratigraphic markers, the ${ }^{137} \mathrm{Cs}$ peaks (1963 and 1986 maxima) and four radiocarbon dates (details in Thevenon et al. 2011a). Ages are in calendar years before/after Christ (BC/AD). The grey-shaded area at the bottom of the core (below $163 \mathrm{~cm}$ ) highlights a turbidite related to a large pre-historic earthquake that occurred in Central Switzerland about 2,200 years ago (Strasser et al. 2006)

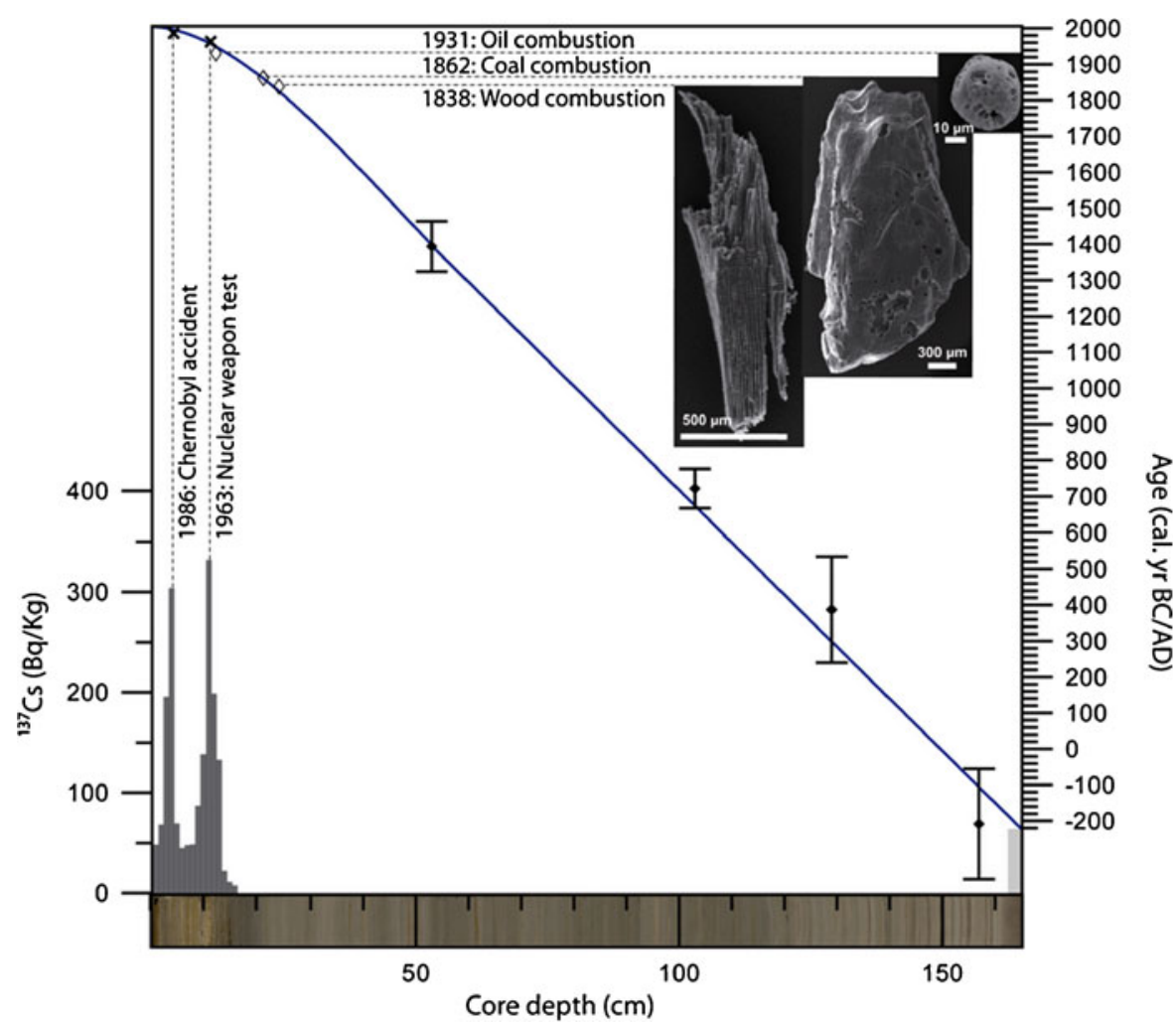

(2012a). Briefly, the bacteria were extracted using Nycodenz gradient centrifugation. The obtained sediment suspension was used for E. coli and ENT quantification and antibiotic susceptibility tests by filtration method. To enumerate $E$. coli and ENT multiple antibiotic resistant, specific dilutions of sediment suspension were spread into appropriate media alone and supplemented with various antibiotic solutions containing the mixture of the following antibiotics: ampicillin, tetracycline, amoxicillin, chloramphenicol and erythromycin. The concentration of antibiotics (greater than minimum inhibitory concentration) and MAR percentages were statistically estimated (Thevenon et al. 2012a).

The PCR assays to assess the presence of resistance genes responsible for Vancomycin (van), $\beta$-lactames gene (blaTEM; amoxicillin/ampicillin), streptomycin/ spectinomycin (aadA), tetracycline (tet) and chloramphenicol $(\mathrm{cmlA})$, was performed in total DNA extracted from sediment sample using different conditions as described by Thevenon et al. (2012a). For FIB, the qualitative PCR assays for the detection of the resistance genes were performed directly in the isolated colonies from the medium free of antibiotics.
The test of microorganism activities in sediments was performed using a commercial ATP test UniLite ${ }^{\circledR} \mathrm{NG}$ luminometer (Floralsolution, Nederland) according to the manufacture's instruction (Thevenon et al. 2011b).

\section{Results and Discussion}

\subsection{Chronostratigraphy of Sediment Cores}

The depth-age models of the studied cores are based on linear and/or polynomial interpolations of samples ages between dated horizons, assuming that sedimentaccumulation rate is relatively constant between adjacent dates. This assumption is an adequate approximation in the deepwater sites of lakes Geneva and Lucerne (Thevenon et al. 2011c). The coring sites have been chosen far away from the inflowing streams and are therefore relatively isolated from coarse terrestrial clastic contribution. The two studied cores lack significant sedimentological disturbances and there is an absence of age inversion (Thevenon et al. 2011c). Although the built depth-age models of the deepwater 
sites of lakes Geneva and Lucerne do not allow high-resolution reconstruction (by comparison with laminated varved sediments), these sequences nonetheless provide consistent records of anthropogenic pollutants over the last centuries on a decadal timescale (Fig. 4).
Fig. 4 Sedimentary trace element records (in micrograms per gram) from the center part of Lake Geneva (304 m water depth) and close to the harbor of Lake Lucerne (110 m water depth). The dashed lines about 1840 and 1960 highlight the maximum trace metal pollution due to the industrial activities in Switzerland during this period. The ${ }^{206} \mathrm{~Pb} /{ }^{207} \mathrm{~Pb}$ record of Lake Lucerne (core 4WS-05; Thevenon et al. 2011c) is reported for comparison

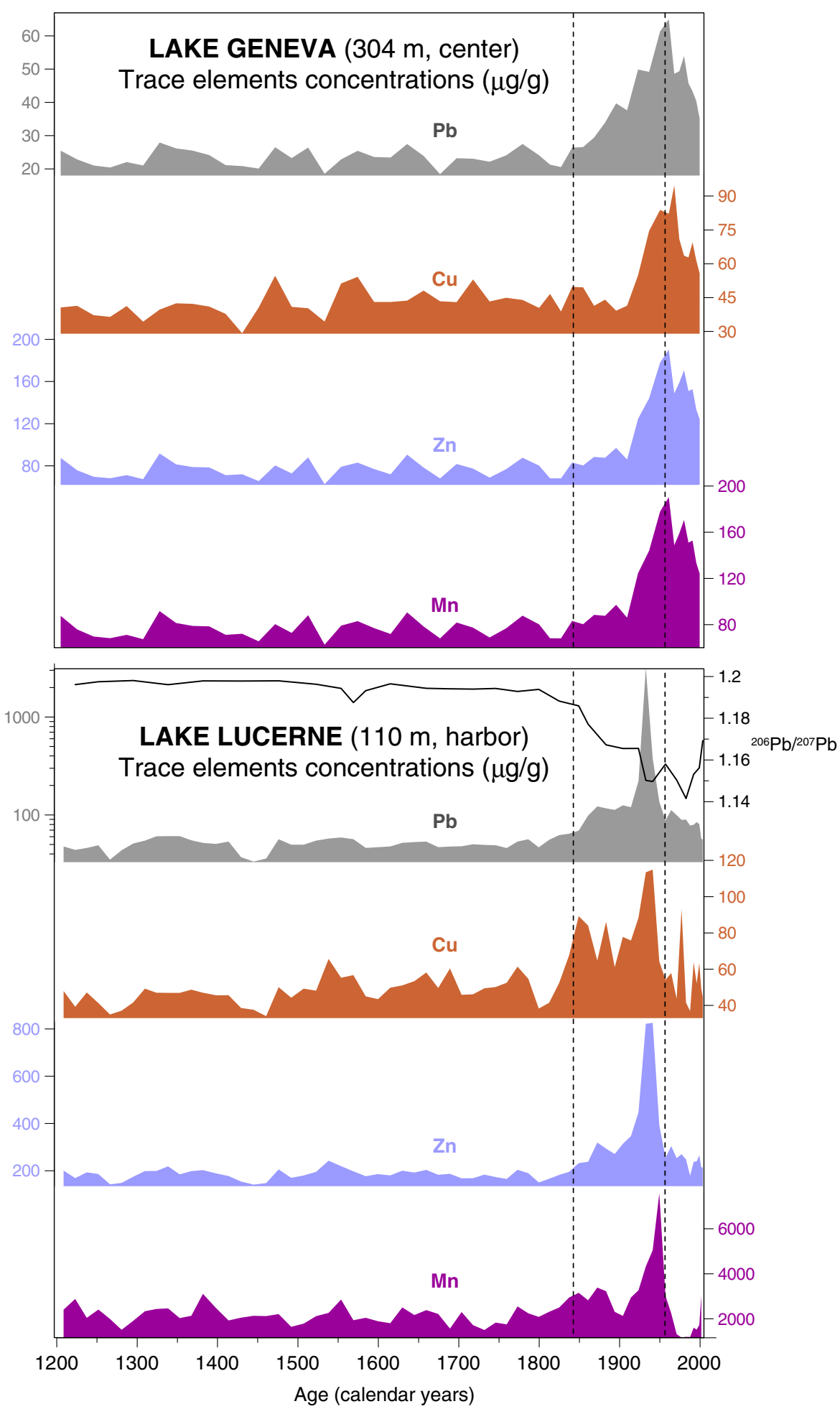


The age-model of the sediment core from Lake Lucerne is explained in detail in Thevenon et al. (2011a) and presented in Fig. 3. To summarise, this age model is based on linear and polynomial interpolations between: the coring year (2005), two distinct ${ }^{137} \mathrm{Cs}$ peaks attributed to the Chernobyl accident in 1986 and to the maximum radionuclide fall-out from atmospheric nuclear tests in 1963/1964 (at 4 and $11 \mathrm{~cm}$, respectively; Fig. 3) and four radiocarbon $\left({ }^{14} \mathrm{C}\right)$ dating performed on terrestrial macrofossils (leaves). Leaves are recommended for ${ }^{14} \mathrm{C}$ dating, because they are brittle vegetation fragments and are therefore unlikely to have been significantly reworked through time (redistributed) before deposition; in contrast to wood fragments or total sedimentary organic matter. The developed age model is in agreement with (1) the apparition of different fossil fuel products (deciphered by their morphology, Fig. 2) during the late nineteenth and early twentieth centuries due to the important steamboat navigation in the vicinity of the city of Lucerne (Thevenon and Anselmetti 2007) and with (2) the turbidite observed below $163 \mathrm{~cm}$ downcore that may be related to a large earthquake that occurred in Switzerland ca. 2,200 years ago (Strasser et al. 2006) (Fig. 2).

The age-models of the sediment cores from Lake Geneva are presented in detail in Thevenon et al. (2011c) based on ${ }^{137} \mathrm{Cs}$ measurement and ${ }^{14} \mathrm{C}$ dating. The absence of the Chernobyl event signature in Lake
Geneva cores may be due to a lower sampling resolution $(2 \mathrm{~cm})$ but natural (e.g. sediment erosion) or anthropogenic disturbances could also not be excluded (Thevenon et al. 2011c). This is particularly the case for the records from the Vidy Bay which clearly evidenced the significant anthropogenic sediment discharge into the bay since 1964 . As a consequence, in this paper, the records from the Vidy Bay are not expressed as a function of time but as a function of depth with some chronological markers reported on Figs. 5 and 7 . In this purpose, the ${ }^{137} \mathrm{Cs}$ profile from a sediment core collected at the same location than core V4 (core Vs14, Glass-Haller 2010) precisely locates the maximum ${ }^{137} \mathrm{Cs}$ fallout in 1963/1964, which strikingly coincides with the implementation of the wastewater treatment plant in the Vidy Bay in 1964 (Fig. 5).

\subsection{Deposition History of Anthropogenic Metal Pollutants}

The trace metal records from the deepwater sites of lakes Geneva and Lucerne combined to the ${ }^{206} \mathrm{~Pb} /{ }^{207} \mathrm{~Pb}$ ratio record of Lake Lucerne indicate a low radiogenic anthropogenic source before the industrial period (Fig. 4). Detailed investigation in Thevenon et al. (2011c) furthermore demonstrates that the trace metal variations before the industrial period were primarily linked to natural weathering input of lithogenic trace elements (titanium and scandium); whereas the stable lead isotope

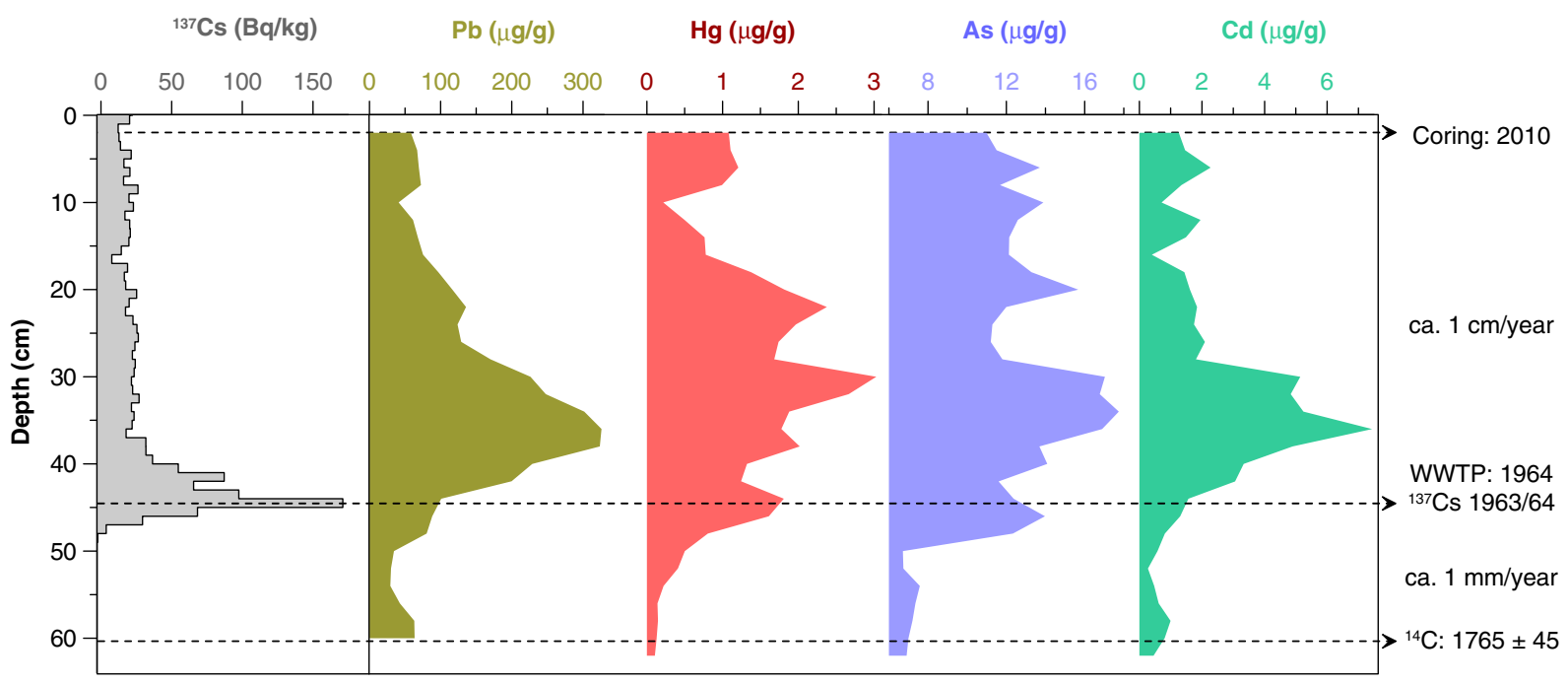

Fig. 5 Sediment record from the Vidy Bay of Lake Geneva (core V4). ${ }^{137} \mathrm{Cs}$ activity (core Vs14, Glass-Haller 2010) compared to trace metals concentrations: lead $(\mathrm{Pb})$, mercury $(\mathrm{Hg})$, arsenic (As) and cadmium (Cd). Chronostratigraphic markers and inferred mean sedimentation rates are reported on the right 
ratios of Lake Lucerne indicate the continuous decline of the lithogenic $\mathrm{Pb}\left({ }^{206} \mathrm{~Pb} /{ }^{207} \mathrm{~Pb} \sim 1.2\right)$ contribution in regards to the long-term increasing anthropogenic lead pollution during the last 500 years (development of metallurgical activities during the High Middle Ages; Fig. 4). Similarly to other large and deep perialpine lakes, a high increase in anthropogenic $\mathrm{Pb}$ deposition took place synchronously with declining isotope ratios following the industrial revolution in Europe around 1850 (Kober et al. 1999; Moor et al. 1996; Arnaud et al. 2004). However, major unanswered questions remain about the origin and the transport of the anthropogenic lead (atmospheric versus aquatic pathways) and more specifically about the impact of the introduction of leaded gasoline in Switzerland in 1947 (characterised by low ${ }^{206} \mathrm{~Pb} /{ }^{207} \mathrm{~Pb}$ ratio of 1.10 ) and unleaded petrol in 1985.

The isotope systematic of $\mathrm{Pb}$ which can be used to determine the origin of $\mathrm{Pb}$, identifies coal combustion and industrial activities as being the main pollutant sources of large perialpine lakes between ca. 1850 and 1950 (Thevenon et al. 2011c). Additionally, the multielement records presented in Fig. $4(\mathrm{~Pb}, \mathrm{Cu}, \mathrm{Zn}$, and $\mathrm{Mn}$ ) for lakes Lucerne and Geneva demonstrate the same pattern of variation for all the measured trace metals, therefore pointing at the same origin (industrial activities) and transport pathway (rivers and runoff waters) during the late nineteenth and early twentieth centuries. It is however noteworthy that the minima ${ }^{206} \mathrm{~Pb} /{ }^{207} \mathrm{~Pb}$ ratio in Lake Lucerne record occurred between ca. 1960 and 1980, when the metal pollution (including $\mathrm{Pb}$ content, Fig. 4) was significantly decreasing due to the implementation of sewage plants around major lakes. Moreover, these results are consistent with peat bog records of atmospheric lead pollution in Switzerland that indicate maximum extent of contamination (primarily supplied by coal burning) in Europe in 1954, which predates the maximum impact of $\mathrm{Pb}$ emissions from the use of leaded gasoline (Shotyk et al. 2002). The changes in stable lead isotope ratios in Lake Lucerne correlate also well with the minimum ${ }^{206} \mathrm{~Pb} /{ }^{207} \mathrm{~Pb}$ ratio evidenced in the years before 1980 in sediment cores from Lake Zug (Central Switzerland), when the traffic emissions were the largest source of $\mathrm{Pb}$ (Moor et al. 1996). Similarly to Lake Constance (NE Switzerland), the apparent absence of a significant gasoline $\mathrm{Pb}$ peak in Lake Lucerne sediments during the 1970s and 1980s could therefore be due to a compensation of the enhanced aeolian $\mathrm{Pb}$ flux (gasoline $\mathrm{Pb}$ ) by a much lower release of fluvial $\mathrm{Pb}$ (building of sewage plants) after 1960 (Kober et al. 1999).

On the contrary to the regional decrease of trace metal input during the second part of the twentieth century (Fig. 4), the discharge of industrial treated wastewaters into Vidy Bay of Lake Geneva after 1964 involved the sedimentation of highly metalcontaminated sediments in the area surrounding the WWTP outlet pipe discharge. Figure 5 exhibits increasing trace metal content $(\mathrm{Pb}, \mathrm{Hg}$, As and $\mathrm{Cd})$ after the $1963 / 1964{ }^{137} \mathrm{Cs}$ peak which coincides with the implementation of the WWTP of Vidy. In the area of WWTP outlet discharge, the surface sediments of the Bay of Vidy present the highest values of trace metals (Fig. 6). The comparison of the metal concentration in surface sediments, before and after the pipe extension in 2001 suggests that the pattern and amplitude of the trace metal deposition significantly changed since the prolongation of the outlet pipe, as exemplified by the total mercury distribution (Fig. 6). In 1996, the sediments show an elongated distribution pattern in a southwest direction whereas the distribution measured in 2005 is more circular, with a small contamination "tail" towards the southeast of the outlet. As a consequence, the strongly impacted surface area decreased from $\sim 1.3$ to $0.8 \mathrm{~km}^{2}$ after the outlet pipe extension. In absence of technical advance to reduce contaminant discharge by the WWTP source, this difference in the spatial distribution of polluted sediments before and after the prolongation of WWTP outlet discharge may be explained by the difference in velocity of lake currents at different water depths (Pardos et al. 2004; Poté et al. 2008).

\subsection{Bacteria Diversity and Faecal Indicator Bacteria Distribution in the Bay of Vidy}

Recent phylogenetic analysis of the bacterial community composition of the surface sediments from the Vidy Bay revealed the dominance of Betaproteobacteria. A large proportion of Betaproteobacteria clones in the Vidy sediments were related to Dechloromonas sp., a dechlorinating bacteria. Deltaproteobacteria, including clones related to sulphate-reducing bacteria and $\mathrm{Fe}$ (III)-reducing bacteria (Geobacter sp.) are particularly abundant in the sediments contaminated by the WWTP effluent in comparison to other parts of Lake Geneva (Haller et al. 2011). In the surface sediments of 


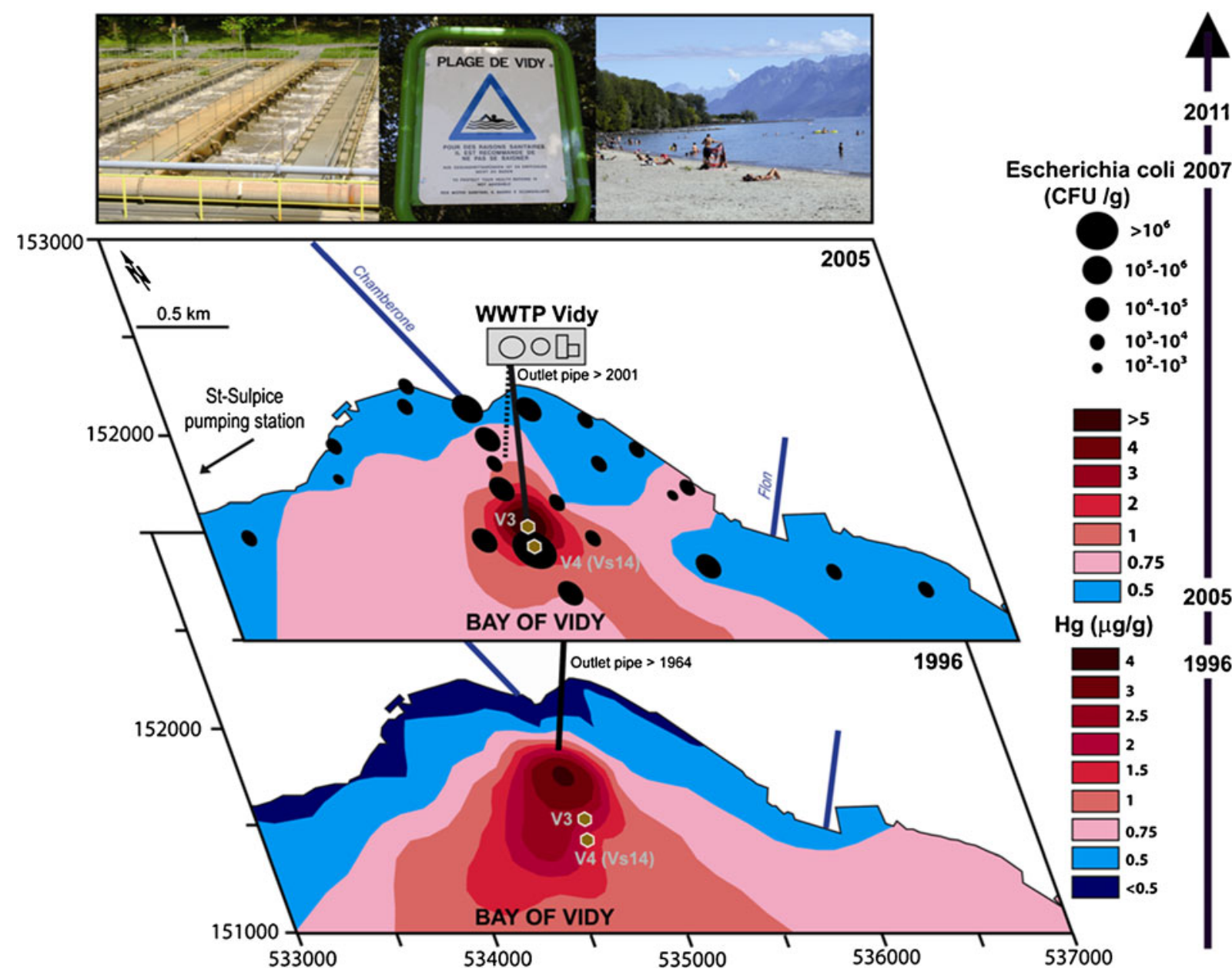

Fig. 6 Upper panel Photographs of the WWTP of Vidy (left) and a view of the beach of Vidy (right) which is highly frequented in summer despite some advertisement (center: "bathing not advisable"). Lower panel: The spatial distribution of the concentration of mercury $(\mathrm{Hg})$ in the surface sediments of Vidy Bay modified from Pote et al. (2008) with the position of the

Vidy Bay, the accumulation of FIB is caused by input from three sources: the WWTP, the Chamberonne and Flon rivers (Fig. 6). The sediment concentrations of FIB throughout all samples taken in the study sites of the Bay of Vidy ranged from $10^{2}$ to $10^{7} \mathrm{CFU} / \mathrm{g}$ sediment. Highest values were obtained in the regions of the WWTP outlet discharge and Chamberonne River with $10^{5}$ to $10^{7}$ (Fig. 6). Results of our previous investigations furthermore indicate that the sediments of the Vidy Bay that are highly enriched in organic matter content (phosphorus, nitrogen and organic carbon) constitute a reservoir of faecal indicator bacteria that can persist in the sediment compartment (Haller et al. 2011; Thevenon cores (V3 and V4; hexagon). The concentration of $\mathrm{Hg}$ in the surface sediments surrounding the actual zone of WWTP outlet discharge in 2005 and the ancient zone of WWTP outlet discharge in 1996. Distribution of E. coli in surface sediments of the Bay of Vidy sampled in July 2007 (modified from Haller et al. 2009)

et al. 2012b). Possible resuspension of FIB and pathogens can therefore occur under changing limnological conditions or human intervention. Such process would increase health risks to sensitive populations during recreational activities in the Vidy Bay and could also affect the drinking water supply.

4.4 FIB Multiple-Antibiotic-Resistant and AntibioticResistant Genes

The temporal distribution of FIB MAR and bacterial activities in the sediments of Lake Geneva do not evidence the same tendency than metal trace elements 


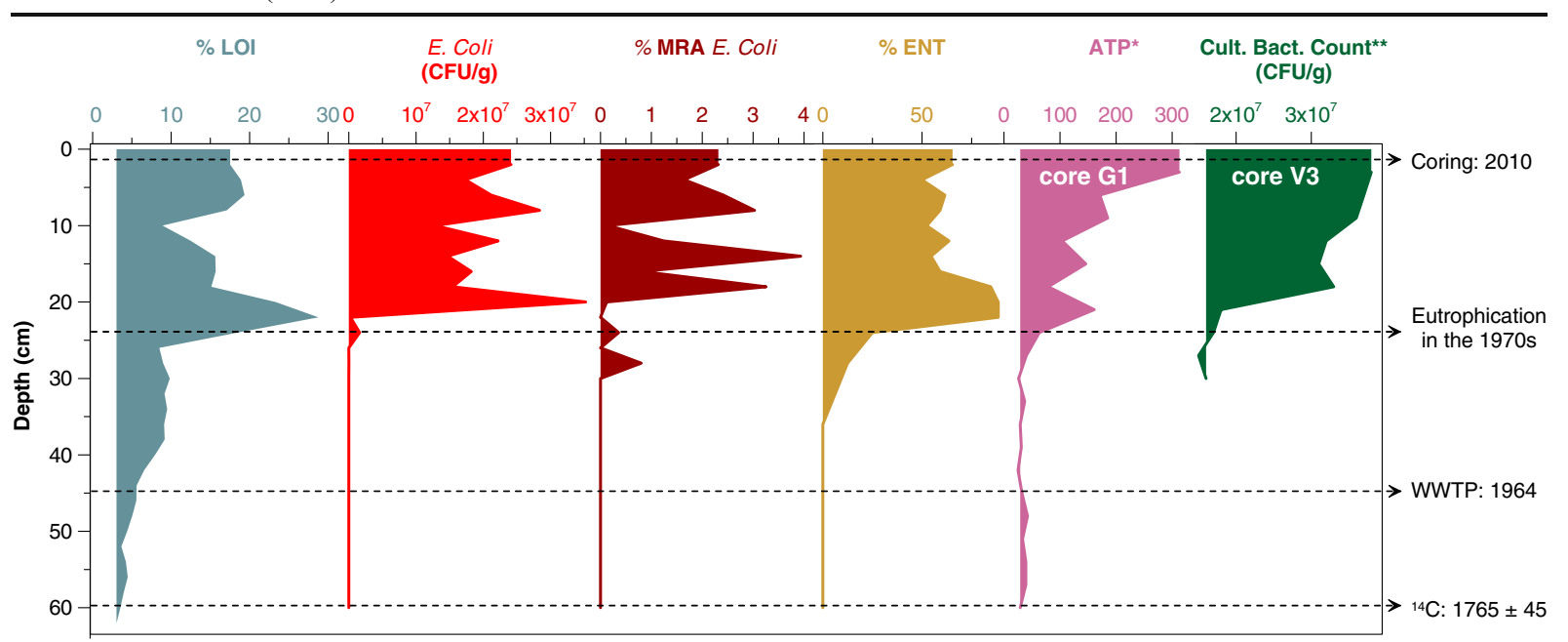

Fig. 7 Sedimentary records from the Vidy Bay of Geneva (core $V 4)$. Weight loss on ignition ( $\% L O I)$ to estimate organic matter content. Isolated E. coli strains ( $C F U / g$ dry sediment), E. coli multiple-resistant antibiotic ( $\% M R A)$ and the percentage of $E$. faecalis $(E N T)$. Adenosine tri-phosphate $(A T P)$ from core G1 and culturable bacteria count ( $C F U / g$ dry sediment) from core V3. The location of these two additional sites is reported on Figs. 1 and 6, and the details about these records can be found in Thevenon et al. (2011b, 2012a)

E. coli and ENT furthermore demonstrate the presence of these resistant genes in all isolated colonies of E. coli and ENT in sediment of the bay of Vidy after 1964 ( 45 cm sediment depth). In addition, the presence of aadA (streptomycin and spectinomycin) resistance gene was found in the sediments deposited before the influence of WWTP effluent water, suggesting that preindustrial sediments constitute a reservoir of specific antibiotic-resistant genes (Thevenon et al. 2012b).

\section{Conclusion}

This review illustrates that combining physicochemical and microbial approaches provide independent and complementary records of anthropogenic pollutants in contrasting sedimentary archives. The trace metal records $(\mathrm{Pb}, \mathrm{Cu}, \mathrm{Zn}$ and $\mathrm{Mn})$ from the deepwater sites from lakes Lucerne and Geneva highlight the regional impact of industrial pollution after ca. 1850 and the general decrease of metal pollution in the 1960s due to the effects of remediation strategies such as the implementation of WWTPs. By opposition, the discharge of treated industrial (and domestic) wastewater in the Vidy Bay of Lake Geneva since 1964 induced a high metal contamination of the sediments surrounding the outlet discharge. Moreover, the faecal indicator bacteria E. coli and human faecal bacteria (E. faecalis) 
highly increased in the sediments contaminated with WWTP effluent following the human-induced eutrophication of Lake Geneva in the 1970s. Bacterial cultures furthermore reveal that the percentage of multiple antibiotic-resistant bacteria and genes synchronously increased. Hence, the human-induced changing limnological conditions highly enhanced the sediment microbial activity and the spreading of antibioticresistant bacteria and genes in this freshwater aquatic environment used to supply drinking water in a highly populated area. The multidisciplinary approach used to quantify anthropogenic trace elements, microbial composition and activity and multi-antibiotic resistant bacteria may be successfully extended to other sedimentary environments such as small drinking water reservoirs located in highly urbanised (or mountainous) areas, in order to assess past and modern anthropogenic sources of water pollution and the pathway of transport of pollutants.

Acknowledgments Coring in Lake Lucerne was performed while F. Thevenon was at the Limnogeology Laboratory, Geological Institute of ETH Zürich, with the support of F. S. Anselmetti and M. Strasser. The present research was financially supported by a grant from the Swiss National Science Foundation (SNSF Ambizione PZ00P2 136899) and received additional funding by the Ernst and Lucie Schmidheiny Foundation. This research is a part of Swiss National Science Foundation (Prodoc Project Leman 21, module 4 (PDFMP2-123048, Project C).

\section{References}

Arnaud, F., Revel-Rolland, M., Bosch, D., Winiarski, T., Desmet, M., Tribovillard, N., et al. (2004). A 300 year history of lead contamination in northern French Alps reconstructed from distant lake sediment records. Journal of Environmental Monitoring, 6, 448-456.

Bührer, H., \& Ambühl, H. (2001). Lake Lucerne, Switzerland, a long term study of 1961-1992. Aquatic Science, 63, 432456.

Cantwell, M. G., Burgess, R. M., \& Kester, D. R. (2002). Release and phase partitioning of metals from anoxic estuarine sediments during periods of simulated resuspension. Environmental Science and Technology, 36, 5328-5334.

Dorioz, J. M., Pelletier, J. P., \& Benoit, P. (1998). Physicochemical properties and bioavailability of particulate phosphorus of various origin in a watershed of Lake Geneva (France). Water Research, 32(2), 275-286.

Glass-Haller, L. (2010). Microbial and geochemical characterization of a contaminated freshwater ecosystem (the case of Vidy Bay, Lake Geneva, Switzerland). Terre et environnement, vol. 95, 186 pages. ISBN 2-940153-94-9.
Haller, L., Amedegnato, E., Poté, J., \& Wildi, W. (2009). Influence of freshwater sediment characteristics on persistence of fecal indicator bacteria. Water, Air, and Soil Pollution, 203, 217-227.

Haller, L., Tonolla, M., Zopfi, J., Peduzzi, R., Wildi, W., \& Poté, J. (2011). Composition of bacterial and archaeal communities in freshwater sediments with different contamination levels (Lake Geneva, Switzerland). Water Research, 45, 1213-1228.

Kober, B., Wessels, M., Bollhöfer, A., \& Mangini, A. (1999). Pb isotopes in sediments of Lake Constance, Central Europe constrain the heavy metal pathways and the pollution history of the catchment, the lake and the regional atmosphere. Geochimica et Cosmochimica Acta, 63, 12931303.

LaLiberte, P., \& Grimes, D. J. (1982). Survival of Escherichia coli in lake bottom sediment. Applied and Environmental Microbiology, 43, 623-628.

Livingstone, D. M. (1997). An example of the simultaneous occurrence of climate-driven "sawtooth" deep-water warming/cooling episodes in several Swiss lakes. Verbal International Vereins Limnologie, 26, 822-828.

Loizeau, J.-L., Pardos, M., Monna, F., Peytremann, P., Haller, L., \& Dominik, J. (2004). The impact of a sewage treatment plant's effluent on sediment quality in a small bay in Lake Geneva (Switzerland-France). Part 2: temporal evolution of heavy metals. Lakes and Reservoirs: Research and Management, 9, 53-63.

Lors, C., Tiffreau, C., \& Laboudigue, A. (2004). Effects of bacterial activities on the release of heavy metals from contaminated dredged sediments. Chemosphere, 56, 619630.

Moor, H. C., Schaller, T., \& Sturm, M. (1996). Recent changes in stable lead isotope ratios in sediments of Lake Zug, Switzerland. Environmental Science and Technology, 30, 2928-2933.

Pardos, M., Benninghoff, C., de Alencastro, L. F., \& Wildi, W. (2004). The impact of a sewage treatment plant's effluent on sediment quality in a small bay in Lake Geneva (SwitzerlandFrance). Part 1: spatial distribution of contaminants and the potential for biological impacts. Lakes and Reservoirs: Research and Management, 9(1), 41-52.

Poté, J., Haller, L., Loizeau, J.-L., Garcia Bravo, A., Sastre, V., \& Wildi, W. (2008). Effects of a sewage treatment plant outlet pipe extension on the distribution of contaminants in the sediments of the Bay of Vidy, Lake Geneva, Switzerland. Bioresource Technology, 99, 7122-7131.

Poté, J., Bravo, A. G., Mavingui, P., Ariztegui, D., \& Wildi, W. (2010). Evaluation of quantitative recovery of bacterial cells and DNA from different lake sediments by Nycodenz density gradient centrifugation. Ecological Indicators, 10, 234-240.

Salomons, W., \& Förstner, U. (1984). Metals in the hydrocycle. Berlin: Springer. 349 p.

Schnellmann, M., Anselmetti, F. S., Giardini, D., McKenzie, J. A., \& Ward, S. N. (2002). Prehistoric earthquake history revealed by lacustrine slump deposits. Geology, 30, 1131-1134.

Schwarzenbach, R. P., Escher, B. I., Fenner, K., Hofstetter, T. B., Johnson, C. A., von Gunten, U., et al. (2006). The challenge of micropollutants in aquatic systems. Science, 313(5790), 1072-1077. 
Shotyk, W., Weiss, D., Heisterkamp, M., Cheburkin, A. K., \& Adams, F. C. (2002). A new peat bog record of atmospheric lead pollution in Switzerland: $\mathrm{Pb}$ concentrations, enrichment factors, isotopic composition and organolead species. Environmental Science and Technology, 36, 3893-3900.

Strasser, M., Anselmetti, F. S., Fäh, D., Giardini, D., \& Schnellmann, M. (2006). Magnitudes and source areas of large prehistoric northern Alpine earthquakes revealed by slope failures in lakes. Geology, 34, 1005-1008.

Thevenon, F., \& Anselmetti, F. S. (2007). Charcoal and fly-ash particles from Lake Lucerne sediments (Central Switzerland) characterized by image analysis: anthropologic, stratigraphic and environmental implications. Quaternary Science Reviews, 26, 2631-2643.

Thevenon, F., Guédron, S., Chiaradia, M., Loizeau, J.-L., \& Poté, J. (2011a). (Pre-) historic changes in natural and anthropogenic heavy metals deposition inferred from two contrasting Swiss Alpine lakes. Quaternary Science Reviews, 30 (1-2), 224-233.

Thevenon, F., Graham, N. D., Hebez, A., Wildi, W., \& Poté, J. (2011b). Spatio-temporal distribution of organic and inorganic pollutants from Lake Geneva (Switzerland) reveals strong interacting effects of sewage treatment plant and eutrophication on microbial abundance. Chemosphere, 84, 609-617.

Thevenon, F., Graham, N. D., Chiaradia, M., Arpagaus, P., Wildi, W., \& Poté, J. (2011c). Local to regional scale industrial heavy metal pollution recorded in sediments of large freshwater lakes in Central Europe (lakes Geneva and Lucerne) over the last centuries. Science of the Total Environment, 412-413, 239-247.

Thevenon, F., Adatte, T., Wildi, W., \& Poté, J. (2012a). Antibiotic resistant bacteria/genes dissemination in lacustrine sediments highly increased following cultural eutrophication of Lake Geneva (Switzerland). Chemosphere, 86, 468-476.

Thevenon, F., Regier, N., Benagli, C., Tonolla, M., Adatte, T., Wildi, W., et al. (2012b). Characterization of faecal indicator bacteria in sediments cores from the largest freshwater lake of Western Europe (Lake Geneva, Switzerland). Ecotoxicology and Environmental Safety, 78, 50-56.

Verweij, F., Booij, K., Satumalay, K., Molen, N., \& Oost, R. (2004). Assessment of bioavailable PAH, PCB and OCP concentrations in water, using semipermeable membrane devices (SPMDs), sediments and caged carp. Chemosphere, $54,1675-1689$.

Vörösmarty, C. J., McIntyre, P. B., Gessner, M. O., Dudgeon, D., Prusevich, A., Green, P., et al. (2010). Global threats to human water security and river biodiversity. Nature, 467, 555-561.

Wang, Q., Kim, D., Dionysiou, D. D., Sorial, G. A., \& Timberlake, D. (2004). Sources and remediation for mercury contamination in aquatic systems - a literature review. Environment Pollution, 131, 323-336. 